\title{
Single tree crown shape and volume models for Pinus nigra planted forests in Italy to support forest management strategies in artificial stands
}

Umberto Di Salvatore ( $\square$ umberto.disalvatore@crea.gov.it )

CREA - Research Centre for Forestry and Wood https://orcid.org/0000-0003-1511-461X

Maurizio Marchi

Istituto di Bioscienze e Biorisorse Consiglio Nazionale delle Ricerche Sezione di Firenze

Paolo Cantiani

CREA - Research Centre for Forestry and Wood

\section{Research}

Keywords: Forest management, Silviculture, Forest ecology, Planted forest, Tree modelling

Posted Date: March 25th, 2020

DOI: https://doi.org/10.21203/rs.3.rs-19299/v1

License: (c) (1) This work is licensed under a Creative Commons Attribution 4.0 International License.

Read Full License 
1 Single tree crown shape and volume models for Pinus nigra planted forests in Italy to support

2 forest management strategies in artificial stands

3

4 Umberto Di Salvatore*1, Maurizio Marchi ${ }^{2}$, Paolo Cantiani ${ }^{3}$

$5 \quad{ }^{1}$ CREA - Research Centre for Forestry and Wood, I-86170 Isernia (Italy)

$6{ }^{2} \mathrm{CNR}$ - Institute of Biosciences and BioResources (IBBR), Via Madonna del Piano 10, I-50019 Sesto

7 Fiorentino (Florence), Italy

$8 \quad{ }^{3}$ CREA - Research Centre for Forestry and Wood, I-52100 Arezzo (Italy)

9

$10 *$ Corresponding Author: umberto.disalvatore@crea.gov.it

11 


\section{Abstract (350 words)}

37 Keywords: Forest management; Silviculture; Forest ecology; Planted forest; Tree modelling

Background: Tree crown can be considered the engine of trees whose size is a key variable to understand the most important ecological and physiological processes that occur in forest ecosystem. The shape and dimension of single-tree crown are affected by a combination of multiple factors such as lateral competition, fertility as well as forest management practices. Anyway, few models are provided in literature to derive their shape and volume from sampled data except the light transmittance or light measurements under canopy closure (Photosynthetic Active Radiation or Leaf Area Index). The main goal of the study is to present a simple and effective method to predict crown shape and crown volume in artificial black pine plantations in Italy from simple field data. Two key parameters involved in crown volume calculation in literature were here modelled. Such parameters were the distance from the top where the crown expresses its the maximum radius $\left(\mathrm{L}_{0}\right)$ and the radius at crown base height $\left(\mathrm{r}_{\mathrm{cb}}\right)$. The analysis of crown profile and volume is based on available knowledge we found in literature (Pretzsch 2009) and where the considered species was not included.

Results: The nonlinear equation results the most adequate for the fitting and able to characterise the ecological processes more properly. Even if just slightly different, the mean absolute error was lower and statistically significant and around $84 \mathrm{~cm}$ for $\mathrm{L}_{0}$ and $36 \mathrm{~cm}$ for $\mathrm{r}_{\mathrm{cb}}$. Then the use of a modelling procedure also allowed the calculation of confidence intervals and was more powerful than a single multiplier, which is the most common method available in literature. Once compared with field data collected during thinning harvesting, the calculated volumes were correlated with thinning intensities and able to characterise the number of trees removed in each treatment and the increased amount of PAR on the ground.

Conclusions: The proposed model results useful to evaluate the spatial structure of forest stand without sophisticated and time-consuming surveys and could be an additional tool to support the practical management of artificial black pine stands. 


\section{Background}

The density of trees influences the shape and dimension of the crown which is the real engine of a tree, where all the physiological processes occur such as photosynthesis, respiration and transpiration (Hemery et al. 2005; Pretzsch 2009; Soto-Cervantes et al. 2016). Crown shape is affected by a combination of multiple factors, including local climate, site conditions, ontogenetic stage, stand density and competition processes (Biging and Gill 1997; Shi and Zhang 2003; Ledermann 2010). In addition to growth trends, also the amount of solar radiation on the ground is connected to both trees' density and crown shape characteristics. This driver has a key role in enhancing all the biological processes in the soil (Coudun et al. 2006; Barbato et al. 2019) and the regeneration/successional dynamics in forests (Page and Cameron 2006) and is the main factor modified by forest management practices (Del Río et al. 2017; Cabon et al. 2018). The shape and distribution of the crowns across a stand define the vertical and horizontal layout, a fundamental attribute to understand the processes of growth and competition in forest ecosystems. Several studies have investigated the relationships between the space occupied by the canopy and other fundamental features of forest ecosystems, such as: i) levels of animal and plant biodiversity (Torras and Saura 2008; Barbato et al. 2019) ii) the degree of inter and intra-specific competition (Page and Cameron 2006; Fichtner et al. 2013; SotoCervantes et al. 2016); iii) the mechanical stability of the trees (Wang et al. 1998; Marchi et al. 2017); iv) assessment of potential behaviour in the event of fire (Martín Santafé et al. 2014; Kim et al. 2016). However, the distribution, composition and vertical structure of forests are only partly determined by the ecological factors and the needs of the individual species, as these have undergone over time the effects of human activities and forest management (Bengtsson et al. 2000; Fady et al. 2016; Olthoff et al. 2016).

The use of indicators and statistical models to support forest management practices is currently increasing (Mäkelä and Pekkarinen 2004; Holopainen et al. 2014; Sharma et al. 2017; Pecchi et al. 2019). The principle behind the indicator concept is that the characteristics of an easily measured feature convey information about more than itself, summarizing and communicating complex 
information in a way that can be quickly understood (Shi and Zhang 2003; Mc Elhinny et al. 2005).

Thus, indicators are of crucial importance to be used for a variety of purposes, such as: describe and diagnose a situation, check the effectiveness of management practices, discriminating among alternative policies, forecast future trends (Lindenmayer et al. 2000; Failing and Gregory 2003; Butchart et al. 2010). Several indicators have been developed to support Sustainable Forest Management (SFM) and part of these are directly derivable from models outputs (Mäkelä et al. 2012).The stand density index (SDI) is probably one of the most used and well known indicator of forest stocking (Pretzsch and Biber 2005; Marchi 2019). This index is represented by a numerical value that captures intensity of competition within forest stands including the volume of the growing stock, age structure and/or diameter distribution, carbon stock and carbon stock changes in forest biomass. Anyway, ecological indicators need to capture the complexities of the ecosystem yet remain simple enough to be easily and routinely monitored (Dale and Beyeler 2001). The (mathematical) simplicity requirements always needs to be achieved with care, without denaturing ecological processes (Marchi 2019).

The single-tree photosynthetic capacity is one of the main indicators of the effects of silvicultural treatments on the competition between trees in forest stands (Cabon et al. 2018). Silvicultural interventions play a fundamental role in the allocation of the foliar mass of forest populations, affecting the competition between trees by modifying the social position (rank) of the released trees, based on the spaces created and the resources ceded by plants that fall when cut. In the present work, two models to predict crown shape and crown volume in artificial Pinus nigra Arnold spp. stands are proposed. The main aim of the paper is to present a simple and effective method to evaluate the spatial structure of forest stand without sophisticated and time-consuming surveys from basic mensurational parameters (DBH, height, etc.), widely available in any national forest inventory dataset and including the amount of photosynthetically active radiation (PAR) on the ground under canopy and measured with time-consuming and expensive tools. A practical use of the model is also proposed in the last 
part of the article by comparing the effects of different silvicultural treatments in black pine artificial

90 plantations.

Materials and Methods

\section{Study areas and raw data}

The dataset used to determine the crown profile model and crown volume consists of 4,171 black pine trees measured during the SelPiBio-LIFE project (Cantiani and Marchi 2017). Stands were located in two different zones of Tuscany called Monte Amiata $\left(42^{\circ} 56^{\prime} 8^{\prime \prime} \mathrm{N}, 11^{\circ} 38^{\prime} 13^{\prime \prime} \mathrm{E}\right.$, mean elevation $780 \mathrm{~m}$ a.s.1.) and Pratomagno $\left(45^{\circ} 27^{\prime} 8^{\prime \prime} \mathrm{N}, 9^{\circ} 11^{\prime} 13^{\prime \prime} \mathrm{E}\right.$, mean elevation $960 \mathrm{~m}$ a.s.1.) and fully described in Cantiani and Marchi (2017). The data were collected in 36 circular fixed area sampling plots (15-m radius), half of which were in each study area (Fig. 1).

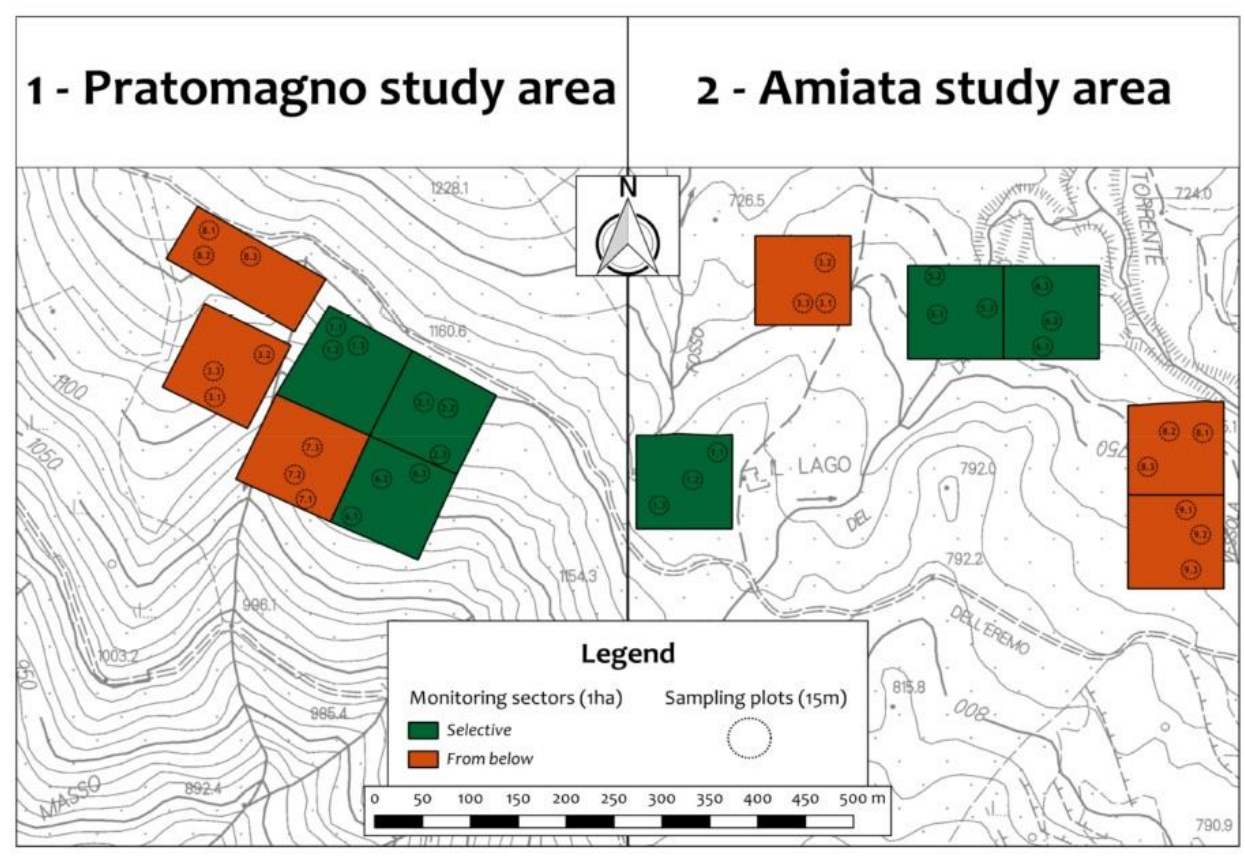

Fig.1 Spatial distribution of monitoring sectors and sampling plots in both of the study areas. The different thinning systems applied are marked with different colours (Marchi et al. 2018).

In each study area, 18 sampling plots randomly located in 6 forest monitoring sectors of 1 ha in size

( 3 plots in each forest monitoring sector) were identified. For all trees the following variables were 
measured: a) the diameter at $1.30 \mathrm{~m}$ height $(\mathrm{DBH})$ using diameter measurement tape; $\mathrm{b})$ total height (Ht), height of first living whorl (Hc) and height at maximum crown width (Hm) using Vertex III; d) the mean crown radius ( $\left.r_{\text {mean }}\right)$ using the vertical sighting method (Pretzsch et al. 2015) as the quadratic mean of eight crown radii, selected to be representative of the crown perimeter and without any prefixed scheme (e.g. N, NE, E, etc..) e) the crown radius at crown base $\left(r_{c b}\right)$; f) the total PAR on the ground. Then the total basal area, total standing volume and total crown volume were calculated for each plot (Table 1).

Table 1 Main mensurational parameters of sampled stands derived from the SelPiBio dataset

\begin{tabular}{|c|c|c|c|c|c|c|}
\hline Site & Species & $\begin{array}{c}\text { Density } \\
{\left[\text { Trees.ha- }^{-1}\right]}\end{array}$ & $\begin{array}{c}\text { Mean DBH } \\
{[\mathrm{cm}]}\end{array}$ & $\begin{array}{c}\text { Mean height } \\
{[\mathrm{m}]}\end{array}$ & $\begin{array}{c}\text { Basal area } \\
{\left[\mathbf{m}^{2} . h^{-1}\right]}\end{array}$ & $\begin{array}{c}\text { Volume } \\
{\left[\mathrm{m}^{3} \cdot \mathbf{h a}^{-1}\right]}\end{array}$ \\
\hline \multirow{3}{*}{$\begin{array}{l}\text { Amiata } \\
(45 \mathrm{yrs})\end{array}$} & Black pine & 959 & 24.3 & 18.1 & 43.6 & 386.4 \\
\hline & Other & 91 & 16.7 & 12.8 & 1.2 & 7.7 \\
\hline & GLOBAL & 1050 & 23.6 & 17.8 & 44.8 & 394.1 \\
\hline \multirow{3}{*}{$\begin{array}{l}\text { Pratomagno } \\
\text { (60 yrs) }\end{array}$} & Black pine & 889 & 29.5 & 19.2 & 59.1 & 538.4 \\
\hline & Other & 188 & 20.5 & 15.5 & 9.5 & 94.2 \\
\hline & GLOBAL & 1077 & 28.7 & 18.8 & 68.6 & 632.6 \\
\hline
\end{tabular}

\section{Crown profile and crown volume equation}

The analysis of crown profile and crown volume structure is currently available for many tree species and based on the use of a model, already used by Central European Authors, evaluating the variation of the radius of crown as the distance from the top increases (Pretzsch 2009). The model uses a segmented approach, dividing the crown (Fig. 2) into an upper (crown part exposed to the sunlight) and lower portion (shaded part of the crown) at the point of the largest crown width. 


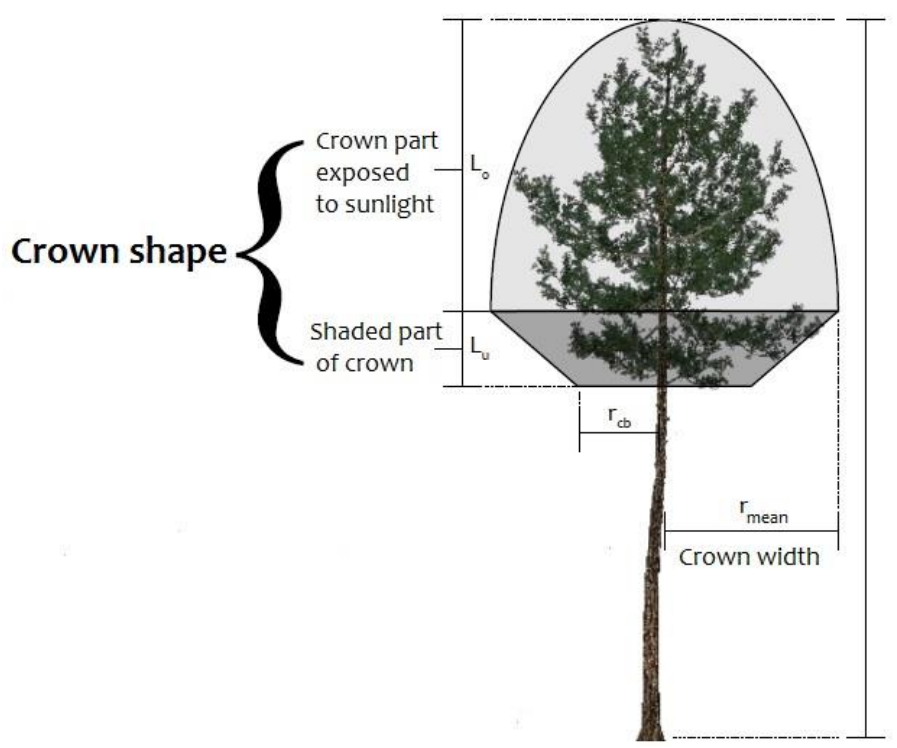

Fig.2 Graphic representation of crown of a softwood tree according to Pretzsch (2009)

125

126 Then the total crown volume (i.e. the space occupied by the canopy) is calculated as the sum of a

127 paraboloid (crown part exposed to the sunlight) and a truncated cone (shaded part of the crown).

128 According to this structure (Fig. 3) the equation for the volume calculation of the two parts are as

129 follows:

$130 \quad V_{\text {light }}=\frac{\pi \cdot r_{\text {mean }}{ }^{2} \cdot L_{0}}{2}[1]$

$131 V_{\text {shade }}=\frac{\pi \cdot\left(r_{\text {mean }}^{2}+r_{\text {mean }}+r_{c b}+r_{c b}{ }^{2}\right) \cdot L_{u}}{3} \quad$ [2]

132 where $r_{\text {mean }}$ is the average crown radius we obtained from 4 or 8 radial measurements, $\mathrm{L}_{0}$ and $\mathrm{L}_{\mathrm{u}}$ are

133 the height of the crown part exposed to the sunlight the height of the shaded part of the crown

134 respectively and $r_{c b}$ is the radius of the smaller circle paced at the bottom of the shaded part of the

135 crown (crown radius at crown base). In this framework, while field data are necessary for $r_{\text {mean, }}$, two

136 models can be fitted to estimate/calculate $\mathrm{L}_{0}$ (and consequently $\mathrm{L}_{\mathrm{u}}$ ) and $\mathrm{r}_{\mathrm{cb}}$ properly from commonly

137 available mensurational parameters. 


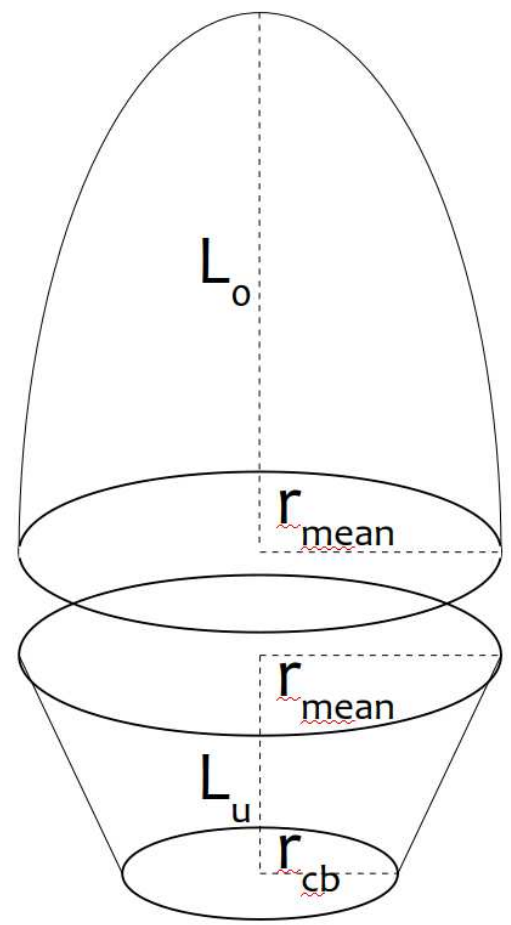

142 Concerning $\mathrm{L}_{0}$, this is often calculated by means of a simple multiplier ranging between 0.5 and 0.6 143 according to the target tree species (Pretzsch 2009). which corresponds (ideally) to the slope of a 144 linear model with intercept forced to zero. Anyway, forcing intercept to zero is often risky. While many biological models should be characterised by zero intercept (e.g. the relationship between DBH and height of a tree), this issue never occurs in practice. Therefore, the liner model has been here

147 fitted allowing intercept to be calculated from data:

$L_{0}=\alpha+\beta \cdot L \quad[3]$

where $\mathrm{L}$ is the total length of the crown, derived as the difference between the total height of the tree and distance of the first living whorl from the ground and $\alpha$ and $\beta$ are the coefficients to be optimised.

151 In addition to model [3] a nonlinear one was fitted too, represented by a power function which often used in ecological studies such as the stand density index calculation (Marchi 2019):

154 with $\mathrm{L}$ as above and $\gamma$ and $\delta$ as regression parameters. Afterwards the $\mathrm{r}_{\mathrm{cb}}$ model was parametrised too 155 using the same models (linear and nonlinear) but replacing $\mathrm{L}_{0}$ and $\mathrm{L}$ with $\mathrm{r}_{\mathrm{cb}}$ and $\mathrm{r}_{\text {mean }}$ respectively. 
156

157

158

159

160

161

162

163

All the equations were parametrised using an existing dataset made by more than 4000 Pinus nigra trees collected in central Italy across artificial stands. The comparison was made performing a cross validation procedure $(\mathrm{CV})$ using a random subset of around $75 \%$ of the data as training and the remaining $25 \%$ of records for testing dataset. CV was repeated $10^{5}$ times and the Mean Absolute Error (MAE) and explained variance (i.e. the $r$ squared, $\mathrm{R}^{2}$ ) were used as indicator of goodness of fit and used to select the best modelling method, averaged to obtain reliable estimates (means). To assess statistical differences, parametric ANOVA was used on MAE and $\mathrm{R}^{2}$ values using the fitted model as treatment. Furthermore, a correlation analysis was run to assess whether the calculated crown characteristics were somehow connected to some structural diversity and inter-tree competition indexes. Among the crown shape features we calculated the ground coverage excluding overlaps (COV), ground coverage with crown overlaps (RIC), volume of the light portion of the crown (LCV), volume of the shaded portion of the crown (SCV), total volume of the crown (TCV). The stand structure indices were the size differentiation index (SDIFF, Pommerening 2002), quadrant index (QI, Cox 1971), Clark and Evans (CE, Clark and Evans 1954), vertical evenness (VE, Neumann and Starlinger 2001), Latham index (LT, Latham et al. 1998), Hegyi competition index (Hegyi, Sharma et al. 2017) as well as derived mensurational parameters such as the number of trees per hectare $(\mathrm{N})$, total basal area per hectare (G.ha), total standing volume per hectare (V.ha), average diameter at breast height $(\mathrm{aDBH})$, average height of the stand $(\mathrm{aH})$ and dominant height (Hdom) we derived from raw data. Finally also a measure of the under canopy Photosynthetically Active Radiation (PAR) was add which was measured by means of different kinds of ceptometers (Sunfleck SF 80, AccuPAR model PAR-80 e LP-80 -Decagon Devices Inc., Pullman, WA, USA) and according to methods already widely tested in the literature (Cutini et al. 2009).

\section{Results}

The comparison between linear and nonlinear models showed the power model as the most adequate for fitting with statistically significant coefficients (and regressions) and good predictive power (Fig. 
4). Even if slight, the MAE was sensibly lower in both cases and statistically significant under coefficients are reported on Table 3.
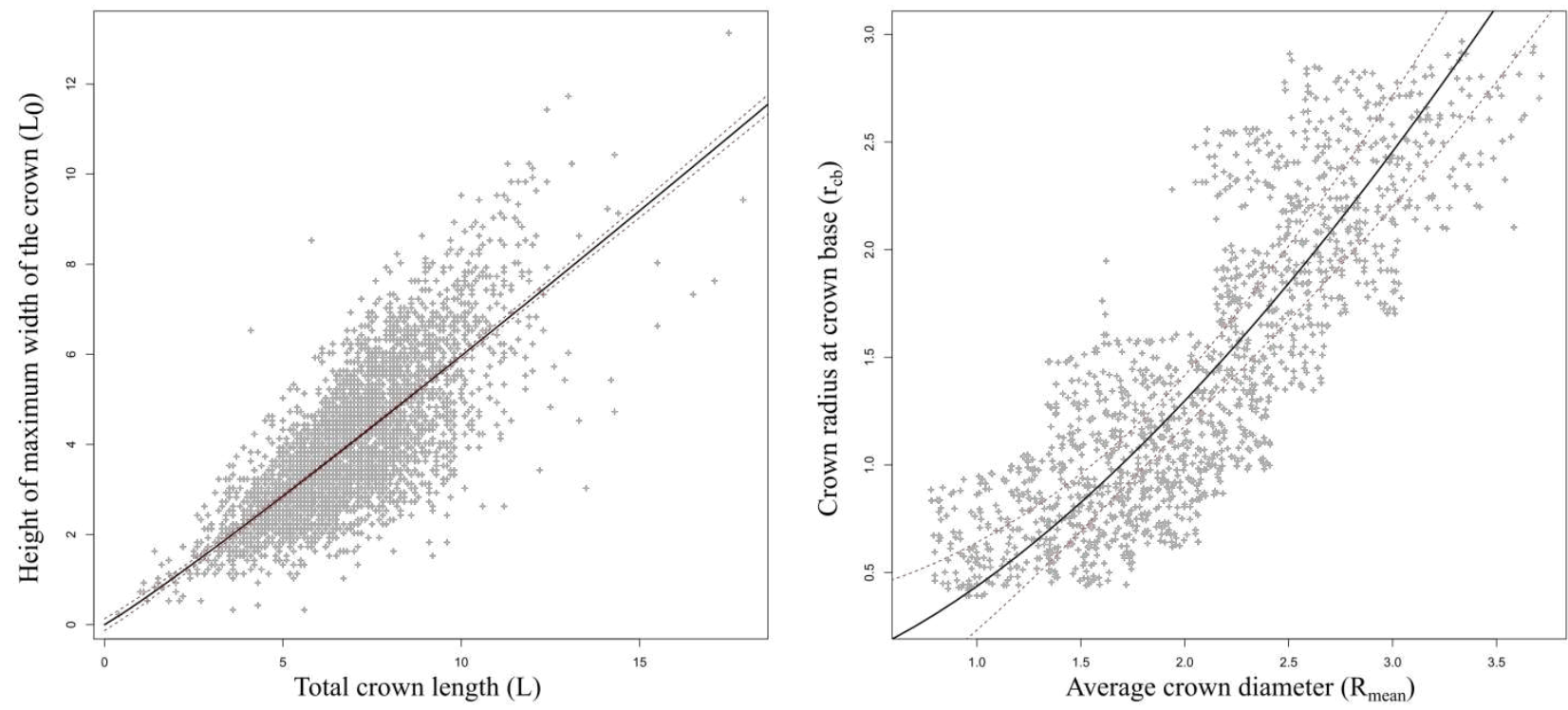

Fig.4 Regression analysis for $L_{0}$ (left) and $r_{c b}$ right. Intervals of confidence (upper and lower) are shown as dotted lines

188

Table 2 Mean Absolute Error (MAE) values obtained from the cross-validation procedure. Number 190 as expressed as meters

\begin{tabular}{|c|c|c|c|c|c|}
\hline Model & Minimum & Median & Mean & St. deviation & Maximum \\
\hline $\mathrm{L}_{0}$ linear & 0.76 & 0.83 & 0.84 & 0.02 & 0.94 \\
\hline $\mathrm{L}_{0}$ nonlinear & 0.76 & 0.84 & 0.84 & 0.02 & 0.94 \\
\hline $\mathrm{r}_{\mathrm{cb}}$ linear & 0.16 & 0.36 & 0.36 & 0.06 & 0.63 \\
\hline $\mathrm{r}_{\mathrm{cb}}$ nonlinear & 0.12 & 0.35 & 0.36 & 0.06 & 0.69 \\
\hline
\end{tabular}

Table 3 Estimated coefficients for equations [4] and [6] for the calculation of $L_{0}$ and $r_{c b}$ parameters

\begin{tabular}{cccccc}
\hline Parameter & Coefficient & Estimate & Std. Error & t value & \multicolumn{1}{c}{$\operatorname{Pr}(>|\mathbf{t}|)$} \\
\hline \multirow{2}{*}{$\mathrm{L}_{0}$} & $\gamma$ & 0.5148 & 0.0178 & 28.900 & $<2 \mathrm{e}-16^{* * *}$ \\
\cline { 2 - 6 } & $\delta$ & 1.0641 & 0.0167 & 63.880 & $<2 \mathrm{e}-16^{* * *}$ \\
\hline \multirow{2}{*}{$\mathrm{r}_{\mathrm{cb}}$} & $\gamma$ & 0.4363 & 0.0591 & 7.389 & $1.19 \mathrm{e}-10^{* * *}$ \\
\cline { 2 - 6 } & $\delta$ & 1.5728 & 0.1535 & 10.244 & $4.85 \mathrm{e}-15^{* * *}$ \\
\hline
\end{tabular}


194 Crown volumes were calculated for each tree and aggregated to obtain plot-level sums. A correlation

195 analysis was then run to assess whether the calculated values were connected to other indices or

196 mensurational parameters derived from the raw data (Table 3).

198 Table 3 Nonparametric (Spearman) correlation coefficients (upper diagonal) and p.values (lower

199 diagonal) between some structural indices calculated with available raw data and crown volumes

200 (light, shade, total)

\begin{tabular}{|c|c|c|c|c|c|c|c|c|c|c|c|c|c|c|c|c|c|c|}
\hline & Nr.ha & G.ha & ha & $\mathrm{BH}$ & $\mathrm{aH}$ & Hdom & diff & QI & E & VE & $\mathrm{Lt}$ & Iegyi & $\mathrm{COV}$ & RIC & PAR & LCV & SCV & $\mathrm{TCV}$ \\
\hline Nr.ha & 1 & 0.330 & 0.223 & $\begin{array}{c}- \\
0.367\end{array}$ & $\begin{array}{c}- \\
0.471\end{array}$ & $\begin{array}{c}- \\
0.090\end{array}$ & 78 & $-\overline{-}$ & & 0.104 & 0.225 & 40 & 37 & 68 & $\begin{array}{c}- \\
0.044\end{array}$ & 14 & 8 & 47 \\
\hline G.ha & 0.015 & 1 & 0.957 & 0.739 & 631 & 0.710 & 0.022 & $\begin{array}{c}- \\
0.092\end{array}$ & & $\begin{array}{c}- \\
0.176\end{array}$ & & 79 & & 69 & $\begin{array}{c}- \\
0.337\end{array}$ & 4 & & 1 \\
\hline V.ha & 0.105 & 0.000 & 1 & 0.774 & 0.710 & 0.847 & $\stackrel{-}{0.006}$ & $\overline{-}$ & 1 & $\begin{array}{c}- \\
0.129\end{array}$ & 0.040 & 0.030 & 39 & 0.205 & $\begin{array}{c}- \\
0.337\end{array}$ & 8 & 0.319 & 6 \\
\hline $\mathrm{aDBH}$ & 0.006 & 0.000 & 0.0 & 1 & 0.973 & 0.775 & $\stackrel{-}{0.033}$ & $\begin{array}{c}- \\
0.069\end{array}$ & 0 & $\begin{array}{c}- \\
0.270\end{array}$ & $\begin{array}{c}- \\
0.138\end{array}$ & $\begin{array}{c}- \\
0.377\end{array}$ & 67 & 0.180 & $\begin{array}{c}- \\
0.350\end{array}$ & 5 & 3 & 73 \\
\hline $\mathrm{aH}$ & 0.000 & 0.000 & 0. & 0.000 & 1 & 0.791 & $\begin{array}{c}- \\
0.109\end{array}$ & $\begin{array}{c}- \\
0.065\end{array}$ & 4 & $\overline{-}-\overline{235}$ & $\begin{array}{c}- \\
0.164\end{array}$ & $\overline{-}-\overline{451}$ & 4 & 0.256 & $\begin{array}{c}- \\
0.380\end{array}$ & 1 & & 2 \\
\hline Hdom & 0.518 & 0.000 & 0. & 0.000 & 0.000 & 1 & $\overline{-}$ & $\begin{array}{c}- \\
0.022\end{array}$ & 00 & $\begin{array}{c}- \\
0.053\end{array}$ & $\begin{array}{c}- \\
0.072\end{array}$ & $\begin{array}{c}- \\
0.247\end{array}$ & 28 & 0.316 & $\begin{array}{c}- \\
0.263\end{array}$ & & & 4 \\
\hline Sdiff & 0.573 & 0.877 & 0.969 & 0.814 & 0.442 & 0.387 & 1 & 0.171 & $\begin{array}{c}- \\
0.179\end{array}$ & $\begin{array}{c}- \\
0.142\end{array}$ & 0.325 & 0.548 & $\overline{-}$ & $\begin{array}{c}- \\
0.249\end{array}$ & 6 & & 2 & 15 \\
\hline QI & 0.798 & 0.512 & 0.648 & 0.622 & 0.646 & 0.879 & 0.239 & 1 & 0.043 & 0.125 & $\begin{array}{c}- \\
0.064\end{array}$ & 0.157 & 0.024 & $\overline{-}$ & 0.066 & -0.065 & 2 & .060 \\
\hline $\mathrm{CE}$ & 0.902 & 0.717 & 0.472 & 0.522 & 0.276 & 0.160 & 0.219 & 0.772 & 1 & 0.022 & 0.072 & $\overline{-}$ & 0.263 & 0.349 & $\begin{array}{c}- \\
0.160\end{array}$ & 0.105 & .159 & 161 \\
\hline VE & 0.455 & 0.207 & 0.357 & 0.051 & 0.094 & 0.713 & 0.329 & 0.397 & 0.884 & 1 & $\begin{array}{c}- \\
0.051\end{array}$ & 0.013 & $\begin{array}{c}- \\
0.194\end{array}$ & 0.072 & 0.179 & 0.140 & .051 & 101 \\
\hline $\mathrm{Lt}$ & 0.102 & 0.756 & 0.776 & 0.324 & 0.244 & 0.614 & 0.023 & 0.664 & 0.629 & 0.735 & 1 & 0.306 & $\begin{array}{c}- \\
0.317\end{array}$ & $\begin{array}{c}- \\
0.094\end{array}$ & 0.275 & 0.011 & 011 & 0.003 \\
\hline Hegyi & 0.000 & 0.573 & 0.829 & 0.005 & 0.001 & 0.080 & 0.000 & 0.287 & 0.047 & 0.929 & 0.040 & 1 & $\begin{array}{c}- \\
0.099\end{array}$ & $\begin{array}{c}- \\
0.201\end{array}$ & 0.039 & -0.096 & 59 & -0.086 \\
\hline $\mathrm{COV}$ & 0.792 & 0.015 & 0.013 & 0.007 & 0.003 & 0.019 & 0.317 & 0.870 & 0.074 & 0.197 & 0.034 & 0.522 & 1 & 0.666 & $\begin{array}{c}- \\
0.879\end{array}$ & .319 & 478 & 487 \\
\hline RIC & 0.626 & 0.226 & 0.141 & 0.198 & 0.067 & 0.023 & 0.084 & 0.389 & 0.016 & 0.634 & 0.540 & 0.190 & 0.000 & 1 & $\begin{array}{c}- \\
0.544\end{array}$ & 322 & 728 & 666 \\
\hline PAR & 0.749 & 0.014 & 0.013 & 0.010 & 0.005 & 0.062 & 0.316 & 0.657 & 0.284 & 0.235 & 0.067 & 0.803 & 0.000 & 0.000 & 1 & -0.383 & -0.384 & -0.484 \\
\hline LCV & 0.410 & 0.000 & 0.000 & 0.000 & 0.000 & 0.000 & 0.583 & 0.663 & 0.484 & 0.354 & 0.944 & 0.536 & 0.039 & 0.040 & 0.080 & 1 & 0.429 & 0.767 \\
\hline SCV & 0.955 & 0.097 & 0.020 & 0.047 & 0.009 & 0.001 & 0.828 & 0.775 & 0.286 & 0.735 & 0.941 & 0.705 & 0.001 & 0.000 & 0.016 & 0.0 & 1 & 0.909 \\
\hline TCV & 734 & 0.003 & 0.000 & 0.000 & 0.000 & 0.000 & 0.921 & 0.686 & 0.279 & 0.504 & 0.984 & 0.579 & 0.001 & 0.000 & 0.011 & 0.0 & .000 & 1 \\
\hline
\end{tabular}

201

202

203

204

205

206

207

208
Acronyms: Nr.ha = number of trees per hectare; G.ha= total basal area per hectare; $V . h a=$ standing volume per hectare; $a D B H=$ average $D B H ; a H=$ average height of the stand; Hdom = dominant height; Sdiff = size differentiation index; $Q I=$ quadrant index; $C E=C l a r k$ and Evans index; $V E=$ vertical evenness index; $L t=$ Latham index; Hegyi $=$ Hegyi index $; C O V=$ ground coverage without crown overlaps; $R I C=$ ground coverage with crown overlaps; $L C V=$ volume of the light portion of the crown; $S C V=$ volume of the shaded portion of the crown; $T C V=$ Total volume of the crown $(L C V+S C V)$ 
According to this analysis the enlighten part of the crown (LCV) was correlated with total standing biomass (i.e. volume per hectare), the average DBH and the dominant height (i.e. the Site index) with was also connected to the volume of the shaded portion of the crown (SCV) and the total crown volume (TCV). Then concerning structural parameters, statistically significant and interesting correlations were found between SCV and the proportion of ground covered by canopy (COV), correlated with TCV too. Concerning PAR, just a negative correlation was found with TCV.

\section{Discussion}

\section{Models to support forest management}

The crown volume values calculated by means of the statistic models represents a step forwards to novel multivariate and multicriteria analysis. Even if small, substantial differences could be defined among models allowing the use of nonlinear equations, probably able to characterise the ecological processes more properly. Parametric and nonparametric models are nowadays seen as mandatory in many research fields, able to provide estimations and confidence intervals at the same time (Aertsen et al. 2010; Petr et al. 2014; Di Biase et al. 2018; Pecchi et al. 2019). Simple multipliers obtained averaging raw data seems to be anachronistic and are not able to detect the variability of the analysed phenomena as well as to provide inferences on the output (Bayer et al. 2013). The difference between model-estimated and multiplier-estimated $\mathrm{L}_{0}$ and $\mathrm{r}_{\mathrm{cb}}$ values can be observed in Fig. 5 where the values predicted by the provided models have been plotted against those calculated with several multiplies ranging between 0.3 and 0.8 as proposed in literature (Pretzsch 2009). While the estimation for $\mathrm{L}_{0}$ showed a small discrepancy with a value for Pinus nigra around 0.68, a pretty different pattern was observed for $\mathrm{r}_{\mathrm{cb}}$ where the curvilinear shape was much more pronounced.

The analysis of the variables that define trees' crown profile and the volume they occupy, provides useful elements to understand the levels of structural diversity of forest ecosystems and therefore, the microclimatic parameters and ultimately the biodiversity levels. Tree crown architecture is essential for tree growth, impacting on biodiversity level on the ground, modelling the amount of light available 
235 for chemical decomposition of organic components and influencing the natural cycle of elements as

236 well as decomposition of organic $\mathrm{CO}_{2}$ stocked in the soil (Jakovljevic et al. 2009; Savi and Fares

237 2014). This is particularity true in artificial black pine stands, a dynamic system where biological

238 processes play a fundamental role for future scenarios and ecological successions (Piermattei et al.

239 2012; Barbato et al. 2019). In this framework a reliable model to predict crown shape and value might

240 open new possibilities, working as indicator of occurrence of biological processes. However, this tool

241 would be influenced by many site-specific feature and, consequently, further attempts should be

242 studied in order to parametrise different models in different conditions and species.

243
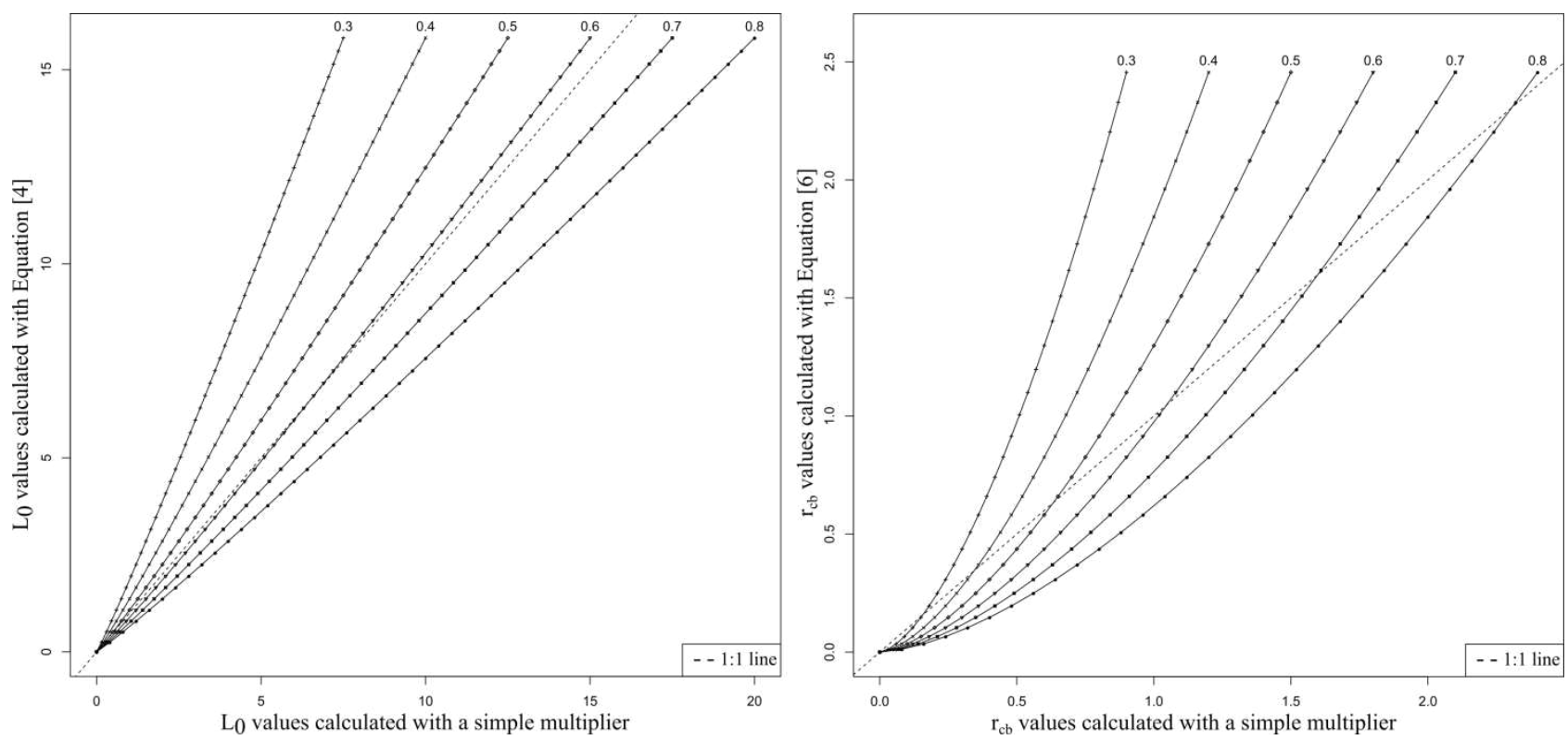

Figure 5 Estimated $L_{0}$ and $r_{c b}$ values predicted by the models (y axis) against values obtained from a

simple multiplier approach (x-axis)

A practical use of models: the SelPiBio LIFE project

A very important aspect is the evaluation of the effects of silvicultural treatments on the space occupied by the canopy in forest stands and how these, quantitatively and qualitatively, affects the photosynthetic capacity and the levels of competition. It is important to keep in mind how silvicultural interventions play a fundamental role in the characterization of the foliar mass of forest populations, going to affect the competitive relationships by modifying the social positions (rank) of the plants 


\begin{tabular}{|c|c|c|c|c|c|c|}
\hline & $\begin{array}{c}\text { Thinning } \\
\text { type }\end{array}$ & $\begin{array}{c}\text { N trees per } \\
\text { ha }\end{array}$ & $\begin{array}{l}\text { Basal } \\
\text { area }\end{array}$ & Biomass & $\begin{array}{c}\text { Crown } \\
\text { Vol }\end{array}$ & PAR \\
\hline \multirow[b]{2}{*}{ AMIATA } & Low thinning & $-30.4 \%$ & $-19.7 \%$ & $-18.7 \%$ & $-11.2 \%$ & $+133 \%$ \\
\hline & $\begin{array}{l}\text { Selective } \\
\text { thinning }\end{array}$ & $-34.3 \%$ & $-31.9 \%$ & $-30.7 \%$ & $-24.4 \%$ & $+413 \%$ \\
\hline \multirow[b]{2}{*}{ PRATOMAGNO } & Low thinning & $-35.9 \%$ & $-22.6 \%$ & $-19.3 \%$ & $-11.3 \%$ & $+87 \%$ \\
\hline & $\begin{array}{l}\text { Selective } \\
\text { thinning }\end{array}$ & $-30.8 \%$ & $-29.4 \%$ & $-29.7 \%$ & $-21.2 \%$ & $+232 \%$ \\
\hline
\end{tabular}
cut. The models we built was the evaluated under the light of a thinning made under the SelPiBio project (www.selpibio.eu). There the here described models might be helpful to quantify the amount of growing space effectively released to the remaining trees without additional and time-consuming field surveys in artificial black pine stands. For instance, a comparison between silvicultural treatment is proposed in Table 4 where the data coming from two different thinning systems on artificial black pine stands (Marchi et al. 2018) were compared using the here provided models. In each study area, 3 forest monitoring sectors were managed by selective thinning ( 3 ha in total, 9 plots per study area) and 3 forest monitoring sectors were managed by low thinning ( 3 ha in total, 9 plots per study area). In the selective thinning, 100 trees per hectare were selected from among the better formed and mechanically stable trees. During cutting, all crown competitors of target trees were harvested to increase their growth (positive selection). In the low thinning, only dominated, small or standing dead trees were harvested (negative selection) during in-field operations.

Table 4 Summary statistics of the effect of two different thinning methods (low and selective thinning) in two artificial black pine stands (Monte Amiata and Pratomagno) where the total crown volume removed was calculated with the models provided in this study

272 When disentangling average values, data became even more interesting if analysed among ranks (Fig.

273 6). Most of the crown volume was allocated (as expected) in co-dominant and dominant trees, only 274 removed with the crown thinning. Even if most of the current thinning schemes are aimed at 
evaluating / limiting the total number of trees per hectares to be removed, the real influence of

276 silvicultural practices should be evaluated in terms of free growing space available for released 277 individuals (i.e. crop trees). In this case the here provided model can support forest managers to

278 estimate this parameter more easily and effectively at low cost

279
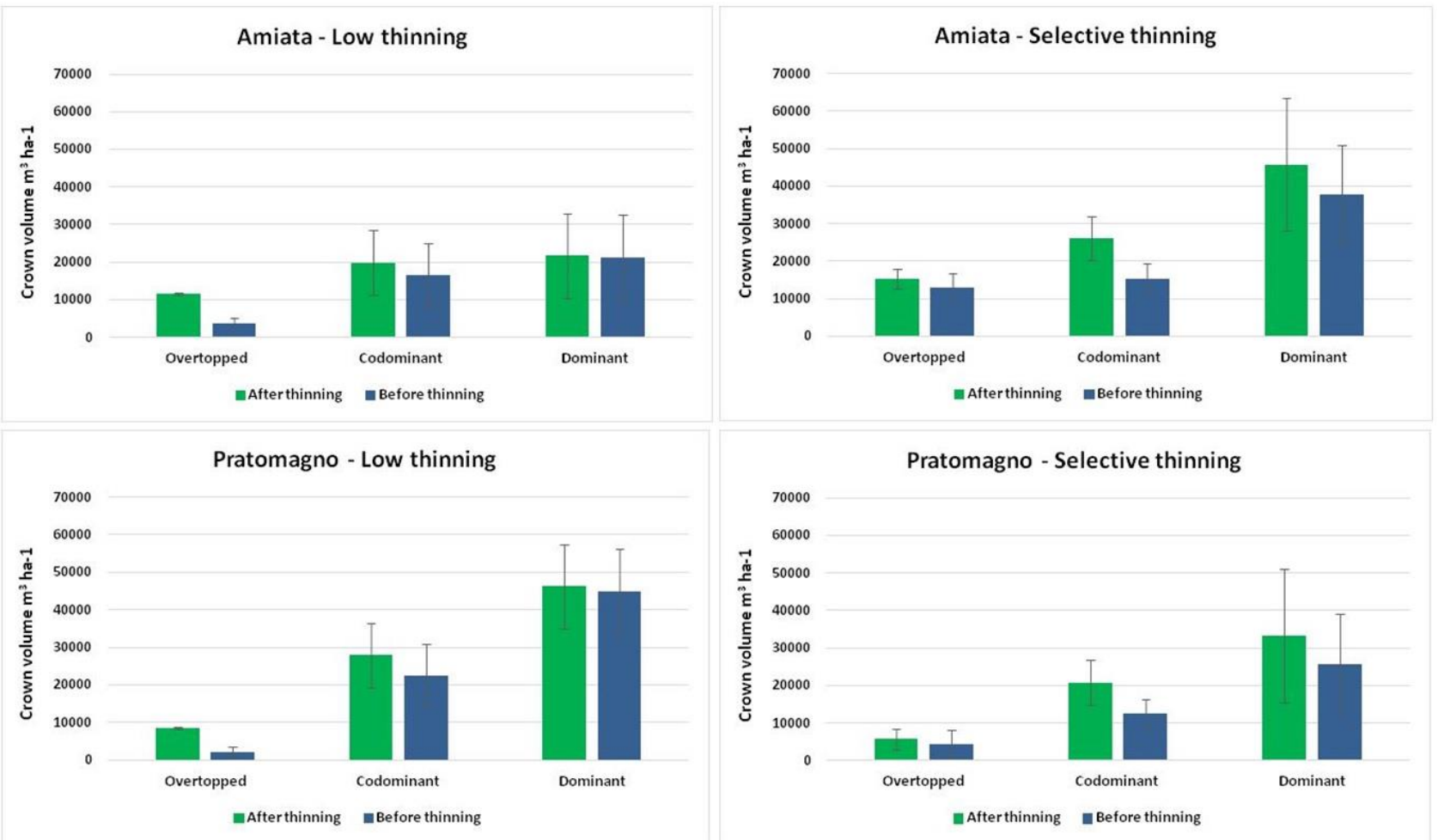

Figure 6 Crown volume removed across the social classes (ranks) in the SelPiBio study case

\section{Conclusions}

Statistical models such as growth models and process-based models can support forest managers and decision-makers to predict/hypothesize the most interesting trajectory for the managed stand. The models we proposed could be considered an additional tool to support the practical management of artificial black pine stands. The further shift towards increasingly mature stages of the pinewoods requires special attention to the evolution and renewal processes of these stands, particularly in the light of current climate change and the high vulnerability of these in relation to phytosanitary risks and fire that could threaten them, undermining their structure and stability. In this context the use of models to predict crown volumes could be used as tool to evaluate the amount of solar radiation 
available on the ground (i.e. PAR) and to balance silvicultural treatments to support the transition to more stable and natural forest systems i.e. the climax by mean natural regeneration of native broadleaves with particular ecological requirements.

\section{Availability of data and materials}

The dataset used and/or analyzed during the current study are available from the corresponding author on reasonable request.

\section{References}

Aertsen W, Kint V, van Orshoven J, et al (2010) Comparison and ranking of different modelling techniques for prediction of site index in Mediterranean mountain forests. Ecol Modell 221:1119-1130. https://doi.org/10.1016/j.ecolmodel.2010.01.007

Barbato D, Perini C, Mocali S, et al (2019) Teamwork makes the dream work: Disentangling crosstaxon congruence across soil biota in black pine plantations. Sci Total Environ 656:659-669. https://doi.org/10.1016/j.scitotenv.2018.11.320

Bayer D, Seifert S, Pretzsch H (2013) Structural crown properties of Norway spruce (Picea abies [L.] Karst.) and European beech (Fagus sylvatica [L.]) in mixed versus pure stands revealed by terrestrial laser scanning. Trees - Struct Funct 27:1035-1047. https://doi.org/10.1007/s00468013-0854-4

Bengtsson J, Nilsson SG, Franc A, Menozzi P (2000) Biodiversity, disturbances, ecosystem function and management of european forests. For Ecol Manage 132:39-50. https://doi.org/10.1016/S0378-1127(00)00378-9

Biging GS, Gill SJ (1997) Stochastic Models for Conifer Tree Crown Profiles. For Sci 43:25-34

Butchart SHM, Walpole M, Collen B, et al (2010) Global biodiversity: Indicators of recent declines. Science (80- ). https://doi.org/10.1126/science.1187512

Cabon A, Mouillot F, Lempereur M, et al (2018) Thinning increases tree growth by delaying 
drought-induced growth cessation in a Mediterranean evergreen oak coppice. For Ecol Manage 409:333-342. https://doi.org/10.1016/j.foreco.2017.11.030

320

Cantiani P, Marchi M (2017) A spatial dataset of forest mensuration collected in black pine plantations in central Italy. Ann For Sci 74:50. https://doi.org/10.1007/s13595-017-0648-8

Clark PJ, Evans FC (1954) Distance to Nearest Neighbor as a Measure of Spatial Relationships in Populations. Ecology. https://doi.org/10.2307/1931034

Coudun C, Gégout JC, Piedallu C, Rameau JC (2006) Soil nutritional factors improve models of plant species distribution: An illustration with Acer campestre (L.) in France. J Biogeogr 33:1750-1763. https://doi.org/10.1111/j.1365-2699.2005.01443.x

Cox F (1971) Dichtebestimmung und Strukturanalyse von Populationen mit Hilfe vonAbstandsmessungen. Göttingen

Cutini A, Chianucci F, Giannini T (2009) Effect of the silvicultural treatment on canopy properties, litter and seed production in beech coppices under conversion to high forest. Eff. del Tratt. Selvic. su Caratter. della copertura Prod. di lettiera e di seme cedui di faggio conversione

Dale VH, Beyeler SC (2001) Challenges in the development and use of ecological indicators. Ecol Indic 1:3-10. https://doi.org/10.1016/S1470-160X(01)00003-6

Del Río M, Bravo-Oviedo A, Pretzsch H, et al (2017) A review of thinning effects on Scots pine stands: From growth and yield to new challenges under global change. For Syst 26:eR03S. https://doi.org/10.5424/fs/2017262-11325

Di Biase RM, Fattorini L, Marchi M (2018) Statistical inferential techniques for approaching forest mapping. A review of methods. Ann Silvic Res 42:46-58. https://doi.org/10.12899/asr-1738

Fady B, Aravanopoulos FA, Alizoti P, et al (2016) Evolution-based approach needed for the conservation and silviculture of peripheral forest tree populations. For Ecol Manage 375:6675. https://doi.org/10.1016/j.foreco.2016.05.015

Failing L, Gregory R (2003) Ten common mistakes in designing biodiversity indicators for forest policy. J Environ Manage 68:121-32. https://doi.org/10.1016/s0301-4797(03)00014-8 
Fichtner A, Sturm K, Rickert C, et al (2013) Crown size-growth relationships of European beech (Fagus sylvatica L.) are driven by the interplay of disturbance intensity and inter-specific competition. For Ecol Manage 302:178-184. https://doi.org/10.1016/j.foreco.2013.03.027

Hemery GE, Savill PS, Thakur A (2005) Height growth and flushing in common walnut (Juglans regia L): 5-Year results from provenance trials in Great Britain. Forestry 78:121-133. https://doi.org/10.1093/forestry/cpi012

Holopainen M, Vastaranta M, Hyyppä J (2014) Outlook for the next generation’s precision forestry in Finland. Forests. https://doi.org/10.3390/f5071682

Jakovljevic T, Berkovic K, Tartari G, et al (2009) Atmospheric Deposition in Forest Ecosystem of Europe and Research of New Methods for Determination of Phosphorus and Ammonia Within A Framework of Icp Forests. Sumar. List 133:267-278

Kim D-W, Chung W, Lee B (2016) Exploring tree crown spacing and slope interaction effects on fire behavior with a physics-based fire model. Forest Sci Technol 12:167-175. https://doi.org/10.1080/21580103.2016.1144541

Latham P, Zuuring H, Coble D (1998) A Method For Quantifying Vertical Forest Structure. For Ecol Manag 104:157-170

Ledermann T (2010) Evaluating the performance of semi-distance-independent competition indices in predicting the basal area growth of individual trees. Can J For Res 40:796-805. https://doi.org/10.1139/X10-026

Lindenmayer DB, Margules CR, Botkin DB (2000) Indicators of biodiversity for ecologically sustainable forest management. Conserv. Biol.

Mäkelä A, Río M del, Hynynen J, et al (2012) Using stand-scale forest models for estimating indicators of sustainable forest management. For. Ecol. Manage. 285:164-178

Mäkelä H, Pekkarinen A (2004) Estimation of forest stand volumes by Landsat TM imagery and stand-level field-inventory data. For Ecol Manage 196:245-255. https://doi.org/10.1016/j.foreco.2004.02.049 
Marchi M (2019) Nonlinear versus linearised model on stand density model fitting and stand density index calculation: analysis of coefficients estimation via simulation. J For Res 30:1595-1602. https://doi.org/10.1007/s11676-019-00967-0

Marchi M, Chiavetta U, Cantiani P (2017) Assessing the mechanical stability of trees in artificial plantations of Pinus nigra J . F . Arnold using the LWN tool under different site indexes. Ann Silvic Res 41:48-53. https://doi.org/10.12899/asr-1312

Marchi M, Paletto A, Cantiani P, et al (2018) Comparing Thinning System Effects on Ecosystem Services Provision in Artificial Black Pine (Pinus nigra J. F. Arnold) Forests. Forests 9:188. https://doi.org/10.3390/f9040188

Martín Santafé M, Pérez Fortea V, Zuriaga P, Barriuso Vargas J (2014) Phytosanitary problems detected in black truffle cultivation. A review. For Syst 20:266-267. https://doi.org/10.5424/fs

Mc Elhinny C, Gibbons P, Brack C, Bauhus J (2005) Forest and woodland stand structural complexity: Its definition and measurement. For. Ecol. Manage. 218:1-24

Neumann M, Starlinger F (2001) The significance of different indices for stand structure and diversity in forests. For Ecol Manage 145:91-106. https://doi.org/10.1016/S03781127(00)00577-6

Olthoff A, Martínez-Ruiz C, Alday JG (2016) Distribution patterns of forest species along an Atlantic-Mediterranean environmental gradient: An approach from forest inventory data. Forestry 89:46-54. https://doi.org/10.1093/forestry/cpv031

Page LM, Cameron AD (2006) Regeneration dynamics of Sitka spruce in artificially created forest gaps. For Ecol Manage 221:260-266. https://doi.org/10.1016/j.foreco.2005.10.006

Pecchi M, Marchi M, Burton V, et al (2019) Species distribution modelling to support forest management. A literature review. Ecol Modell 411:108817. https://doi.org/10.1016/j.ecolmodel.2019.108817

Petr M, Boerboom L, Ray D, van der Veen A (2014) An uncertainty assessment framework for forest planning adaptation to climate change. For Policy Econ 41:1-11. 
397 Piermattei A, Renzaglia F, Urbinati C (2012) Recent expansion of Pinus nigra Arn. above the timberline in the central Apennines, Italy. Ann For Sci 69:509-517. https://doi.org/10.1007/s13595-012-0207-2

Pommerening A (2002) Approaches to quantifying forest structures. Forestry 75:305-324. https://doi.org/10.1093/forestry/75.3.305

Pretzsch H (2009) Forest Dynamics, Growth and Yield

Pretzsch H, Biber P (2005) A Re-Evaluation of Reineke's Rule and Stand Density Index. For Sci 51:304-320

Pretzsch H, Biber P, Uhl E, et al (2015) Crown size and growing space requirement of common tree species in urban centres, parks, and forests. Urban For Urban Green 14:466-479. https://doi.org/10.1016/j.ufug.2015.04.006

Savi F, Fares S (2014) Ozone dynamics in a Mediterranean Holm oak forest: comparison among transition periods characterized by different amounts of precipitation. Ann Silvic Res 38:1-6. https://doi.org/10.12899/asr-801

Sharma RP, Vacek Z, Vacek S (2017) Modelling tree crown-to-bole diameter ratio for Norway spruce and European beech. Silva Fenn 51:. https://doi.org/10.14214/sf.1740

Shi H, Zhang L (2003) Local Analysis of Tree Competition and Growth. For Sci 49:938-955. https://doi.org/10.1093/forestscience/49.6.938

Soto-Cervantes JA, López-Sánchez CA, Corral-Rivas JJ, et al (2016) Desarrollo de un modelo de perfil de copa para pinus cooperi blanco en la UMAFOR 1008, durango, México. Rev Chapingo, Ser Ciencias For y del Ambient 22:179-192. https://doi.org/10.5154/r.rchscfa.2015.09.040

Torras O, Saura S (2008) Effects of silvicultural treatments on forest biodiversity indicators in the Mediterranean. For Ecol Manage 255:3322-3330. https://doi.org/10.1016/j.foreco.2008.02.013 Wang Y, Titus SJ, LeMay VM (1998) Relationships between tree slenderness coefficients and tree 


\section{Acknowledgements}

426 Authors wish to thank Valter Cresti, Maurizio Piovosi, Manuela Plutino, Luca Marchino, Alice

427 Angelini, Mirko Grotti and Giulia Rinaldini from CREA - Research Centre for Forestry and Wood 428 for the external assistance during the survey campaign.

\section{Funding}

431 This study was carried out and funded by the SelPiBio LIFE project (Innovative silvicultural 432 treatments to enhance soil biodiversity in artificial black pine stands, LIFE13 BIO/IT/000282) for 433 demonstration of innovative silvicultural treatments in artificial black pine stands 434 (https://www.selpibio.eu/en/).

\section{Author information}

\section{Affiliations}

438 Umberto Di Salvatore: CREA - Research Centre for Forestry and Wood, I-86170 Isernia (Italy),

439 Maurizio Marchi: CNR - Institute of Biosciences and BioResources (IBBR), Via Madonna del Piano

440 10, I-50019 Sesto Fiorentino (Florence), Italy

441 Paolo Cantiani: CREA - Research Centre for Forestry and Wood, I-52100 Arezzo (Italy)

\section{Contributions}

444 All the Authors contributed equally in this paper and approved the submitted version of the 445 manuscript 
448 Correspondence to Umberto Di Salvatore.

449

450 Ethics declarations

451 Ethics approval and consent to participate

452 Not applicable.

453

454 Competing interests

455 The authors declare that they have no competing interests.

456 